\title{
Germination Responses of Purpletop and Big Bluestem Caryopses Subjected to Distilled Water or Potassium Nitrate Prechilling, Sodium Hypochlorite, and Storage
}

\author{
Michael W. Olszewski ${ }^{1,3}$ and Grant J. Folin ${ }^{2}$ \\ Department of Landscape Architecture and Horticulture, Temple University, \\ 580 Meetinghouse Road, Ambler, PA 19002
}

Additional index words. Tridens flavus, Andropogon gerardii, warm-season grass seed, native plants, restoration

\begin{abstract}
Purpletop [Tridens flavus (L.) Hitchc.] and big bluestem (Andropogon gerardii Vitman) are incorporated into native grass seed mixes for use in ecological restoration. Alleviation of low seed vigor and poor stand establishment would benefit the restoration process by increasing the animal habitat in restored zones. This study determined the effectiveness of prechilling with distilled water $\left(\mathrm{dH}_{2} \mathrm{O}\right)$ versus potassium nitrate $\left(\mathrm{KNO}_{3}\right)$, sodium hypochlorite $(\mathrm{NaOCl})$ treatments, and short-term storage conditions on seed germination, seedling growth, and stand establishment of purpletop and big bluestem. Prechilling of 'Niagara, NY Ecotype' big bluestem for 7 days at $5{ }^{\circ} \mathrm{C}$ in $\mathrm{dH}_{2} \mathrm{O}$ increased final germination percentage (FGP) and germination rate provided caryopses were not dried before sowing. Optimal FGP, germination rate, and germination synchrony were obtained for 'VA Ecotype' purpletop after prechilling for 14 days at $5{ }^{\circ} \mathrm{C}$ in $\mathrm{dH}_{2} \mathrm{O}$ without subsequent caryopsis drying or at $0.2 \% \mathrm{KNO}_{3}$ with or without subsequent caryopsis drying. Prechilling increased germination synchrony for purpletop but not for big bluestem. NaOCl treatments did not enhance germination or seedling vigor of purpletop or big bluestem. Using nonstored, prechilled caryopses resulted in greater root lengths than stored caryopses or nontreated controls, although optimal purpletop growth required that they be sowed moist, whereas optimal big bluestem growth required that they be dried-back before sowing. In greenhouse experiments, higher seeding rates were correlated with increased number of seedlings for nontreated or prechilled big bluestem and for prechilled purpletop, but not for nontreated purpletop, which had poor stand establishment at all seeding rates. The results indicate that prechilling of caryopses before incorporation into a warm-season grass seed mix increased seedling establishment of purpletop but not big bluestem.
\end{abstract}

Purpletop is a warm-season perennial grass native to the United States that grows in dry fields or along roadsides in 36 states (Brown, 1979; USDA-NRCS, 2009b). It is able to grow within a variety of soil types and $\mathrm{pH}$ levels, including soils that are highly eroded (Foote and Jackobs, 1966). Removal of the palea and lemma of the caryopsis fruit (dehulling) and stratification for $14 \mathrm{~d}$ at $3{ }^{\circ} \mathrm{C}$ overcomes purpletop dormancy (USDA-NRCS, 2006); however, dehulling does not increase purpletop stand establishment (USDA-NRCS, 1996). Dormancy of purpletop is at least partly the result of seed-covering structures because their removal decreases time to germination, although mechanical scarification did not increase germination percentage or germination uniformity (Olszewski et al., 2009). Publica-

Received for publication 23 Jan. 2009. Accepted for publication 27 Apr. 2009.

${ }^{1}$ Assistant Professor.

${ }^{2}$ Undergraduate Student.

${ }^{3}$ To whom reprint requests should be addressed; e-mailolszewsk@temple.edu. tions regarding seed dormancy are lacking for many grass genera, including Tridens (Simpson, 1990).

Big bluestem grows in dry open areas, along roadsides, or within fields in 43 states (Brown, 1979; USDA-NRCS, 2009a). In Pennsylvania, birds in warm-season grass fields containing big bluestem have greater nest success than those containing cool-season grasses (Giuliano and Daves, 2002). There are no specific competition effects among species of warm-season grasses during early establishment (Launchbaugh and Owensby, 1970); however, Robocker et al. (1953) determined that Canada wild rye (Elymus canadensis L.) grew more quickly than big bluestem. Among germinating members of orchardgrass (Dactylis glomerata L.), early-emerging individuals have competitive advantages over later-emerging individuals (Ross and Harper, 1972).

Presowing wet chilling (prechilling) of big bluestem caryopses in $0.2 \% \mathrm{KNO}_{3}$ for 14 d at $4{ }^{\circ} \mathrm{C}$ caused an increase of the temperature at which maximum germination percentage and germination rate occur (Hsu et al., 1985). Although big bluestem laboratory testing indicated that germination increased after solid matrix priming ( $-6 \mathrm{MPa}$ for $2 \mathrm{~d}$ at $17{ }^{\circ} \mathrm{C}$ or $14 \mathrm{~d}$ at $4{ }^{\circ} \mathrm{C}$ ), sowing nontreated caryopses resulted in higher field emergence than primed caryopses under dry environmental conditions (Beckman et al., 1993). Long-duration after-ripening and scarification of big bluestem caryopses were effective seed enhancement techniques and the mechanism of dormancy was hypothesized to result from seed-covering structures restricting gas exchange (Coukos, 1944).

If seeding is delayed, then caryopses may have to be stored. Storage temperatures of 16 to $27^{\circ} \mathrm{C}$ resulted in big bluestem germinating in higher percentages than those stored at cooler storage temperatures of 1 to $6{ }^{\circ} \mathrm{C}$ (Coukos, 1944). Because we know of no reports comparing $\mathrm{H}_{2} \mathrm{O}$ versus $\mathrm{KNO}_{3}$ during prechilling, the effects of posttreatment storage conditions on germination and seedling growth, and subsequent incorporation of prechilled caryopses into warm-season grass seed mixes, the following studies were undertaken using purpletop and big bluestem.

\section{Materials and Methods}

Single seedlots of 'VA Ecotype' purpletop, 'Niagara, NY Ecotype' big bluestem, 'PA Ecotype' Canadian wild rye (Elymus canadensis L.), 'Rumsey' Indiangrass [Sorghastrum nutans (L.) Nash.], 'Camper' little bluestem [Schizachyrium scoparium (Michx.) Nash], and 'Shelter' switchgrass (Panicum virgatum L.) were purchased from Ernst Conservation Seeds (Meadville, PA) and used for the following experiments. After purchase of seed lots, the caryopses were stored under cool and dry conditions $\left[7{ }^{\circ} \mathrm{C}\right.$ and $32 \%$ relative humidity $(\mathrm{RH})$ ] for 7 (Expts. 1 and 2) or 12 (Expt. 3) months before experiments started. Little bluestem was used immediately after purchase and was not stored.

Expt. 1: Prechilling effects. Caryopses were subjected to prechilling by incubating $1.0 \mathrm{~g}$ caryopses between two layers of germination No. 385 blotters (Seedburo Co., Chicago, IL) moistened with $20 \mathrm{~mL}$ of $0.2 \%\left(\mathrm{~m} / \mathrm{v}\right.$; AOSA, 2007) $\mathrm{KNO}_{3}$ or $\mathrm{dH}_{2} \mathrm{O}$ contained in $125 \times 80 \times 20$-mm transparent polystyrene boxes with tight-fitting lids for 7 or $14 \mathrm{~d}$ at $5{ }^{\circ} \mathrm{C}$ in darkness. Moisture lost as a result of evaporation from blotters was replaced with $\mathrm{dH}_{2} \mathrm{O}$. After prechilling, one group of caryopses from each treatment was blotted with germination blotter and immediately sowed (moist caryopses). Another group of caryopses was subjected to drying at $23{ }^{\circ} \mathrm{C}$ and $48 \% \mathrm{RH}$ for $7 \mathrm{~d}$. Drying began in such a way that all experimental treatments ended simultaneously. Nontreated caryopses were included as a control. Caryopses were placed into polystyrene boxes containing two layers of germination blotters moistened with $20 \mathrm{~mL}$ of $\mathrm{dH}_{2} \mathrm{O}$ and incubated at $20 / 30{ }^{\circ} \mathrm{C}$ $(14 / 10 \mathrm{~h})$ with $70 \mu \mathrm{mol} \cdot \mathrm{m}^{-2} \cdot \mathrm{s}^{-1}$ photosynthetically active radiation $(P A R)$ during the warmer period fulfilling germination requirements for big bluestem (AOSA, 2007) and 
purpletop (USDA-NRCS, 2006). Each polystyrene box contained 50 caryopses with four replications (boxes) per treatment arranged in a completely randomized block design. The number of seeds germinated (those having a visible coleorhiza/radicle) were counted daily and removed. From these counts, the angular transformation [arcsin $\sqrt{ } \%$ transformation in degrees (deg.); Gomez and Gomez, 1984] of final germination percentage (FGP), days to $50 \%$ FGP $\left(\mathrm{G}_{50}\right.$, an inverse measure of germination rate), and days between $10 \%$ and $90 \%$ FGP $\left(\mathrm{G}_{10-90}\right.$, an inverse measure of germination synchrony) were subjected to analysis of variance (ANOVA) using PROC GLM (SAS 9.1; SAS Institute, Inc., Cary, NC).

Expt. 2: NaOCl treatments and caryopsis storage. To minimize seed deterioration by storage fungi, caryopses of purpletop and big bluestem receiving prechilling treatment $\left(5^{\circ} \mathrm{C}\right.$ in $0.2 \% \mathrm{KNO}_{3}$ for $14 \mathrm{~d}$ ) were subjected to $10 \%$ chlorine bleach-soaking $(\mathrm{v} / \mathrm{v} ; 0.6 \%$ $\mathrm{NaOCl})$ before storage. Caryopses $(1.0 \mathrm{~g})$ were enclosed in cheesecloth and soaked in $\mathrm{NaOCl}$ containing $0.015 \%$ (w/v) Tween-20 for $10 \mathrm{~min}$ (pretreatment with $\mathrm{NaOCl}$ ) and then rinsed in running water for $10 \mathrm{~min}$. One group of caryopses was not treated with $\mathrm{NaOCl}$. After prechilling, caryopses that previously were treated with $\mathrm{NaOCl}$ were enclosed in cheesecloth and soaked in $\mathrm{NaOCl}$ containing $0.015 \%(\mathrm{w} / \mathrm{v})$ Tween-20 for $5 \mathrm{~min}$ (posttreatment with $\mathrm{NaOCl}$ ) and then rinsed in running water for $10 \mathrm{~min}$. Caryopses then were blotted with germination blotter (moist caryopses) or dried as previously described in Expt. 1 before storage. Storage conditions were constant darkness at 5 or $21{ }^{\circ} \mathrm{C}$ contained within a $15 \times 33-\mathrm{cm}$ polyethylene bag No. 21 (Seedburo Co., Chicago, IL) heatsealed with a Model 210-8G Impulse Bag Sealer (Clamco Corp., Cleveland, $\mathrm{OH}$ ). Nontreated and nonstored caryopses were used as controls.

Slant tests were used to determine seed vigor (Smith et al., 1973). One cut germination blotter No. 385 of $75 \times 120$-mm size was placed into each polystyrene box. Each blotter was soaked in a phosphate buffer $(3.8 \mathrm{~g}$ $\mathrm{KH}_{2} \mathrm{PO}_{4}+10.2 \mathrm{~g} \mathrm{~K}_{2} \mathrm{HPO}_{4} / \mathrm{L} \mathrm{dH} \mathrm{H}_{2} \mathrm{O} ; \mathrm{pH}=$ 7.0) until saturation. Fifteen caryopses were placed equidistantly $1.5 \mathrm{~cm}$ from the top of the blotter with the radicle end of each caryopsis facing downward. A lid then was placed on top to prevent moisture loss. Caryopses and boxes then were placed into trays at approximately a $70^{\circ}$ angle. The 2 (storage temperature) $\times 2$ (moist or dry caryopsis storage) $\times 2$ (with or without $\mathrm{NaOCl}$ treatments) factorial with six replications of 15 caryopses was arranged in a completely randomized block design within an incubator. The assay was conducted using Expt. 1 incubation conditions. After 14 $\mathrm{d}$ incubation, shoot and root lengths were measured with a vernier caliper. FGP and its angular transformation (deg.) and shoot and root lengths $(\mathrm{mm})$ were calculated and subjected to ANOVA using PROC GLM.

Expt. 3: Seed mixes with prechilled caryopses. Native warm-season grass seed mixes were tested because they are used in the northeastern United States for erosion control (Miller and Dickerson, 1999). The prechilling laboratory treatment yielding the highest FGP and lowest $\mathrm{G}_{50}\left(14 \mathrm{~d}\right.$ at $5{ }^{\circ} \mathrm{C}$ in $0.2 \% \mathrm{KNO}_{3}$ for purpletop and $7 \mathrm{~d}$ at $5{ }^{\circ} \mathrm{C}$ in distilled water for big bluestem) were selected for greenhouse experiments. Purpletop or big bluestem caryopses were nontreated or prechilled followed by blotting with germination blotter immediately before sowing (moist-sowed caryopses). All warmseason grass seed mixes contained 20 seeds of Canadian wild rye, Indiangrass, little bluestem, and switchgrass. Mixtures also contained 10, 20, or 50 seeds of big bluestem and 10,20, or 50 seeds of purpletop. Mixtures were sowed into moistened proprietary media (Redi-Earth Plug and Seedling Mix; SunGro Horticulture, Bellevue, WA) contained in $27 \times 53 \times 6$-cm plastic trays. Seed mixtures were spread evenly over an area of $0.064 \mathrm{~m}^{2}$ and lightly covered with $\approx 2 \mathrm{~mm}$ of media. Media were irrigated as needed and arranged in a completely randomized block design with four replications in a greenhouse with filtered natural light (July/August; 187 $\left.\mu \mathrm{mol} \cdot \mathrm{m}^{-2} \cdot \mathrm{s}^{-1} P A R\right)$ at $18 / 29{ }^{\circ} \mathrm{C}$ (minimum/ maximum). For identification, a key of vegetative characteristics was used (Phillips, 1962) as well as live references as shown in Figure 1. The number of emerged seedlings were counted 4 weeks after sowing and subjected to ANOVA on seeding rates using PROC GLM with linear regression.

\section{Results}

Expt. 1: Prechilling effects. All prechilling treatments of purpletop increased germination rate (lower $\mathrm{G}_{50}$ values) and synchrony (lower $\mathrm{G}_{10-90}$ values) except for $7 \mathrm{~d}$ prechilling in $\mathrm{dH}_{2} \mathrm{O}$ with or without subsequent airdrying, which did not increase synchrony (Table 1). Prechilling of purpletop caryopses for $14 \mathrm{~d}$ in $\mathrm{dH}_{2} \mathrm{O}$, without air-drying, or for 14 $\mathrm{d}$ in $\mathrm{KNO}_{3}$, with or without air-drying, increased FGP compared with nontreated caryopses. Longer durations of purpletop prechilling increased FGP (group mean) from $82 \%$ to $91 \%$ after 7 - versus $14-d$ treatment durations, respectively. Purpletop caryopses that were prechilled in $\mathrm{KNO}_{3}$ and air-dried before the germination assay had earlier germination than those prechilled in $\mathrm{dH}_{2} \mathrm{O}$ and air-dried. Prechilling of big bluestem caryopses for $7 \mathrm{~d}$ in $\mathrm{dH}_{2} \mathrm{O}$ or for $14 \mathrm{~d}$ in $\mathrm{KNO}_{3}$, without subsequent air-drying, increased FGP. The germination rate of big bluestem was increased by a single treatment $\left(\mathrm{dH}_{2} \mathrm{O}\right.$ for $7 \mathrm{~d}$ at $5{ }^{\circ} \mathrm{C}$, nondried caryopses); however, none of the experimental treatments increased germination synchrony.

Expt. 2: Caryopsis storage. Seedlings developing from nonstored purpletop and big bluestem prechilled caryopses had the longest root lengths, although optimal purpletop seedling growth occurred when prechilled caryopses were moist-sowed, whereas optimal big bluestem seedling growth occurred when prechilled caryopses were subjected to

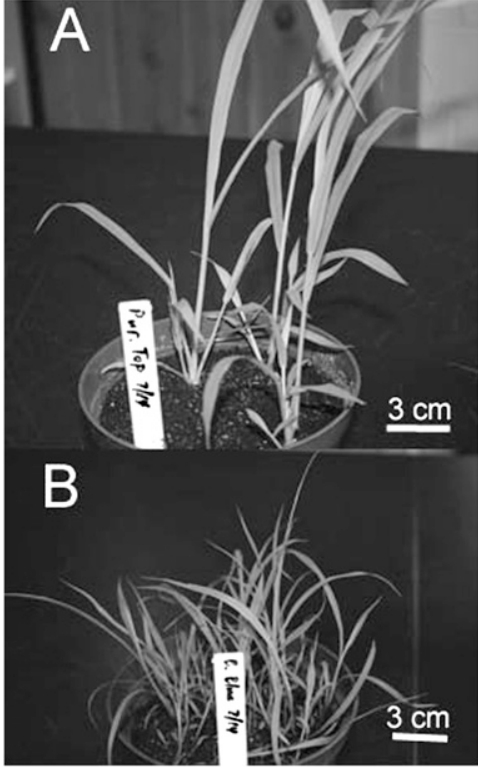

Fig. 1. Four-week-old seedlings of (A) purpletop and (B) big bluestem.

drying before sowing (Table 2). Pre- and posttreatments with $\mathrm{NaOCl}$ did not enhance germination or seedling vigor of purpletop or big bluestem; however, precocious germination occurred during $21{ }^{\circ} \mathrm{C}$ moist storage with $\mathrm{NaOCl}$ for big bluestem and purpletop $(8 \%$ and less than $1 \%$ germination, respectively; data not shown). Precocious germination also occurred for purpletop and big bluestem (both less than $1 \%$ germination; data not shown) during $21{ }^{\circ} \mathrm{C}$ moist storage with no $\mathrm{NaOCl}$ treatment. Storage of prechilled and $\mathrm{NaOCl}-$ treated big bluestem caryopses in a moist condition at $21{ }^{\circ} \mathrm{C}$ for $10 \mathrm{~d}$ reduced FGP. Storage of prechilled, dried-back purpletop caryopses at 5 or $21{ }^{\circ} \mathrm{C}$ for $10 \mathrm{~d}$ reduced FGP and shoot lengths compared with prechilled, moist-stored caryopses.

Expt. 3: Seed mixes with prechilled caryopses. There were no slope differences of regressions for nontreated versus prechilled big bluestem, but there were slope differences for nontreated versus prechilled purpletop (data not shown). According to the regression analysis, seedling number was positively correlated with higher seeding rate for nontreated or prechilled big bluestem ( $r^{2}=0.95$ and 0.83 , respectively) and prechilled purpletop $\left(r^{2}=0.85\right.$; Fig. 2$)$. However, there was no correlation $\left(r^{2}=0.22\right)$ between number of seedlings and seeding rates for nontreated purpletop caryopses.

\section{Discussion}

Although certified germination was $77 \%$ and $96 \%$ for big bluestem and purpletop, respectively (Ernst Conservation Seeds, Meadville, PA), FGP of nontreated seed was $46 \%$ and $75 \%$, respectively (Table 1 ). The shortest duration of $\mathrm{dH}_{2} \mathrm{O}$ or $\mathrm{KNO}_{3}$ prechilling necessary to increase FGP of purpletop was $14 \mathrm{~d}$. Germination of purpletop was $91 \%$ for moist-sowed caryopses prechilled in $\mathrm{dH}_{2} \mathrm{O}$ 
Table 1. Final germination percentage (FGP) and its angular transformation (deg.), days to $50 \%$ of FGP $\left(\mathrm{G}_{50}\right)$, and days between $10 \%$ and $90 \%$ of $\mathrm{FGP}\left(\mathrm{G}_{10-90}\right)$ of purpletop and big bluestem caryopses at alternating $20 / 30{ }^{\circ} \mathrm{C}(14 / 10 \mathrm{~h}$, dark/light $) .^{\mathrm{z}}$

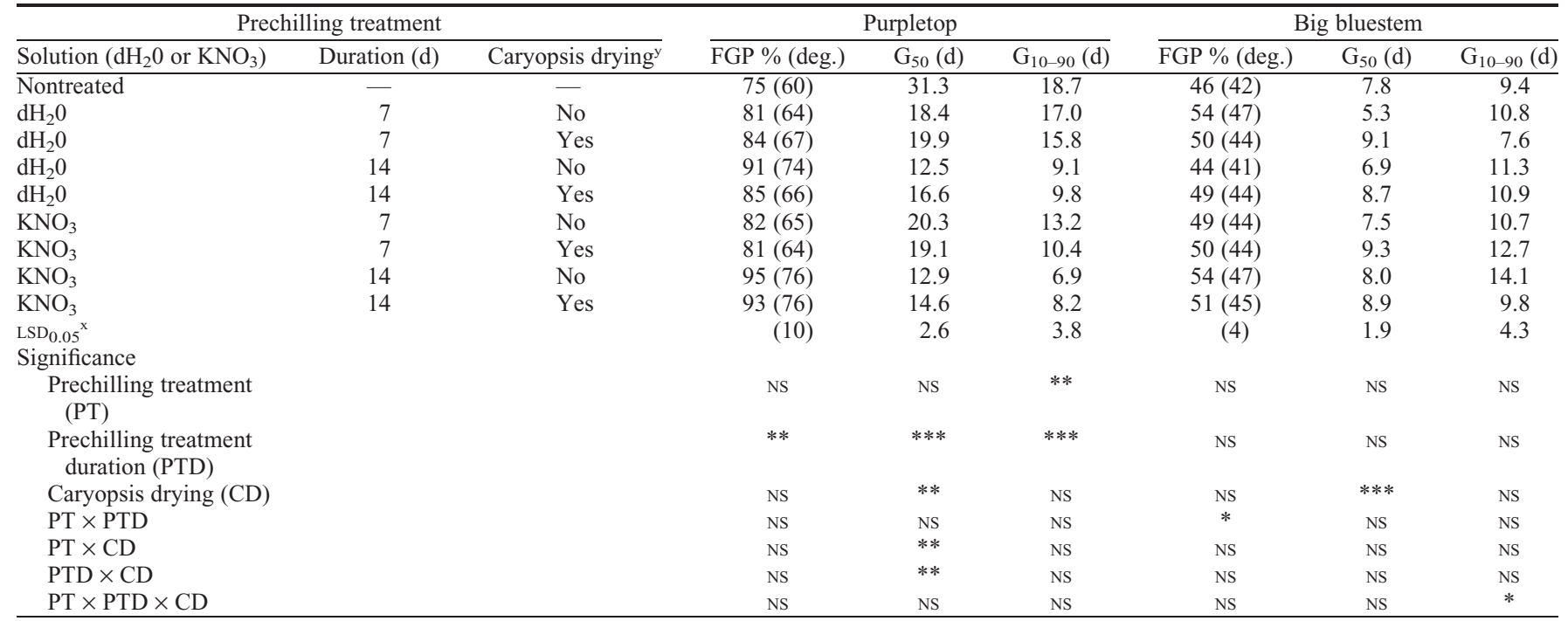

${ }^{2}$ Caryopses were prechilled at $5{ }^{\circ} \mathrm{C}$ in $\mathrm{dH}_{2} 0$ or $0.2 \% \mathrm{KNO}_{3}$ for 7 or $14 \mathrm{~d}$ and then sowed after nondrying or drying.

${ }^{y}$ Caryopsis drying commenced immediately after prechilling treatment and was accomplished by air-drying at $23{ }^{\circ} \mathrm{C}$ and $48 \%$ relative humidity for $7 \mathrm{~d}$.

${ }^{\mathrm{x}} \mathrm{LSD}_{0.05}=$ Fisher's protected least significant difference among treatments by plant species.

Ns, $* * *, * *$ Nonsignificant or significant at $P \leq 0.05, \leq 0.01$, or $\leq 0.001$, respectively.

Table 2. Final germination percentage (FGP) and its angular transformation (deg.), shoot length (mm), and root length (mm) of purpletop and big bluestem $14 \mathrm{~d}$ after planting caryopses onto a slant test apparatus at alternating $20 / 30{ }^{\circ} \mathrm{C}(14 / 10 \mathrm{~h}$, dark/light $) .{ }^{\mathrm{z}}$

\begin{tabular}{|c|c|c|c|c|c|c|c|c|}
\hline \multicolumn{3}{|c|}{ Caryopsis storage } & \multicolumn{3}{|c|}{ Purpletop } & \multicolumn{3}{|c|}{ Big bluestem } \\
\hline Temperature $\left({ }^{\circ} \mathrm{C}\right)$ & $\begin{array}{c}\text { Condition } \\
(\text { dry/moist })^{\mathrm{x}}\end{array}$ & $\begin{array}{l}\mathrm{NaOCl}^{\mathrm{y}} \\
\text { treatment }\end{array}$ & $\begin{array}{l}\text { FGP \% } \\
\text { (deg.) }\end{array}$ & $\begin{array}{l}\text { Shoot length } \\
(\mathrm{mm})\end{array}$ & $\begin{array}{l}\text { Root length } \\
\text { (mm) }\end{array}$ & $\begin{array}{l}\text { FGP \% } \\
\text { (deg.) }\end{array}$ & $\begin{array}{l}\text { Shoot length } \\
(\mathrm{mm})\end{array}$ & $\begin{array}{l}\text { Root length } \\
\text { (mm) }\end{array}$ \\
\hline Nontreated & - & - & $0(2)$ & 0.0 & 0.0 & $29(32)$ & 5.1 & 2.4 \\
\hline 5 & Dry & No & $46(42)$ & 4.7 & 1.9 & $30(33)$ & 8.6 & 2.1 \\
\hline 5 & Dry & Yes & $16(21)$ & 2.1 & 0.7 & $29(32)$ & 7.6 & 2.1 \\
\hline 5 & Moist & No & $72(59)$ & 6.5 & 1.6 & $25(29)$ & 8.0 & 2.0 \\
\hline 21 & Dry & Yes & $17(23)$ & 2.3 & 1.4 & $34(35)$ & 6.4 & 1.9 \\
\hline 21 & Moist & No & $64(53)$ & 7.8 & 2.0 & $22(28)$ & 4.3 & 1.8 \\
\hline 21 & Moist & Yes & $52(46)$ & 6.6 & 1.2 & $11(17)$ & 2.8 & 1.5 \\
\hline $\operatorname{LSD}_{0.05^{\mathrm{v}}}$ & & & (12) & 2.0 & 1.5 & (10) & 3.6 & 1.2 \\
\hline \multicolumn{9}{|l|}{ Significance } \\
\hline Storage temperature (ST) & & & (NS) & NS & NS & (NS) & ** & NS \\
\hline Storage condition (SC) & & & $(* * *)$ & $* * *$ & NS & $(* *)$ & NS & NS \\
\hline
\end{tabular}

${ }^{2}$ Caryopses were nontreated or prechilled $\left(0.2 \% \mathrm{KNO}_{3}\right.$ for $14 \mathrm{~d}$ at $\left.5{ }^{\circ} \mathrm{C}\right)$ and nonstored or stored for $10 \mathrm{~d}$ within heat-sealed plastic pouches in dry or moist condition with or without chlorine bleach $(\mathrm{NaOCl})$ treatments.

${ }^{\mathrm{y}}$ Chlorine bleach treatments consisted of soaking caryopses in $0.6 \% \mathrm{NaOCl}$ plus $0.015 \%$ (w/v) Tween- 20 for 10 min before prechilling plus $5 \mathrm{~min}$ after prechilling. ${ }^{\mathrm{x}}$ Caryopsis drying commenced immediately after prechilling treatment and was accomplished by air-drying at $23{ }^{\circ} \mathrm{C}$ and $48 \%$ relative humidity for $7 \mathrm{~d}$.

"Nonstored caryopses were sowed as dried-back or moist seed at the time of planting.

${ }^{\mathrm{LSD}_{0.05}}=$ Fisher's protected least significant difference among treatments by plant species.

Ns, $*, * * * * *$ Nonsignificant or significant at $P \leq 0.05, \leq 0.01$, or $\leq 0.001$, respectively.

for $14 \mathrm{~d}$. Purpletop germination also was improved (higher FGP, lower $\mathrm{G}_{50}$, and lower $\mathrm{G}_{10-90}$ ) after a prechilling treatment in $\mathrm{KNO}_{3}$ for $14 \mathrm{~d}$. The most significant benefit of using $\mathrm{KNO}_{3}$ versus $\mathrm{dH}_{2} \mathrm{O}$ was increased germination synchrony for purpletop. The effect of nitrate ions on grass seed germination has been reviewed elsewhere (Simpson, 1990); however, exact reasons for germination stimulation remain elusive. Beckman et al. (1993) showed that seed hydration treatments (prim- ing) for $2 \mathrm{~d}$ at $17{ }^{\circ} \mathrm{C}$ or for $14 \mathrm{~d}$ at $4{ }^{\circ} \mathrm{C}$ increased big bluestem emergence. In the current study, big bluestem FGP was increased by prechilling at $5{ }^{\circ} \mathrm{C}$ in $\mathrm{dH}_{2} \mathrm{O}$ for 7 $\mathrm{d}$ or at $5{ }^{\circ} \mathrm{C}$ in $\mathrm{KNO}_{3}$ for $14 \mathrm{~d}$ provided that caryopses were not dried before sowing. Either the degree of dormancy or the type of dormancy is different from purpletop because prechilling treatments that alleviated purpletop dormancy were not as effective for big bluestem.
Air-drying of primed caryopses for $7 \mathrm{~d}$ reduced FGP of bottlebrush squirreltail [Sitanion hystix (Nutt.) J.G. Smith]; storage (up to $70 \mathrm{~d}$ ) of primed and air-dried caryopses resulted in loss of germination benefits of canby bluegrass (Poa canbyi Scribn; Hardegree, 1994). Thus, any benefits imparted by grass seed hydration treatments may be lost after storage or drying procedures. Drying prechilled big bluestem caryopses followed by immediate sowing resulted 

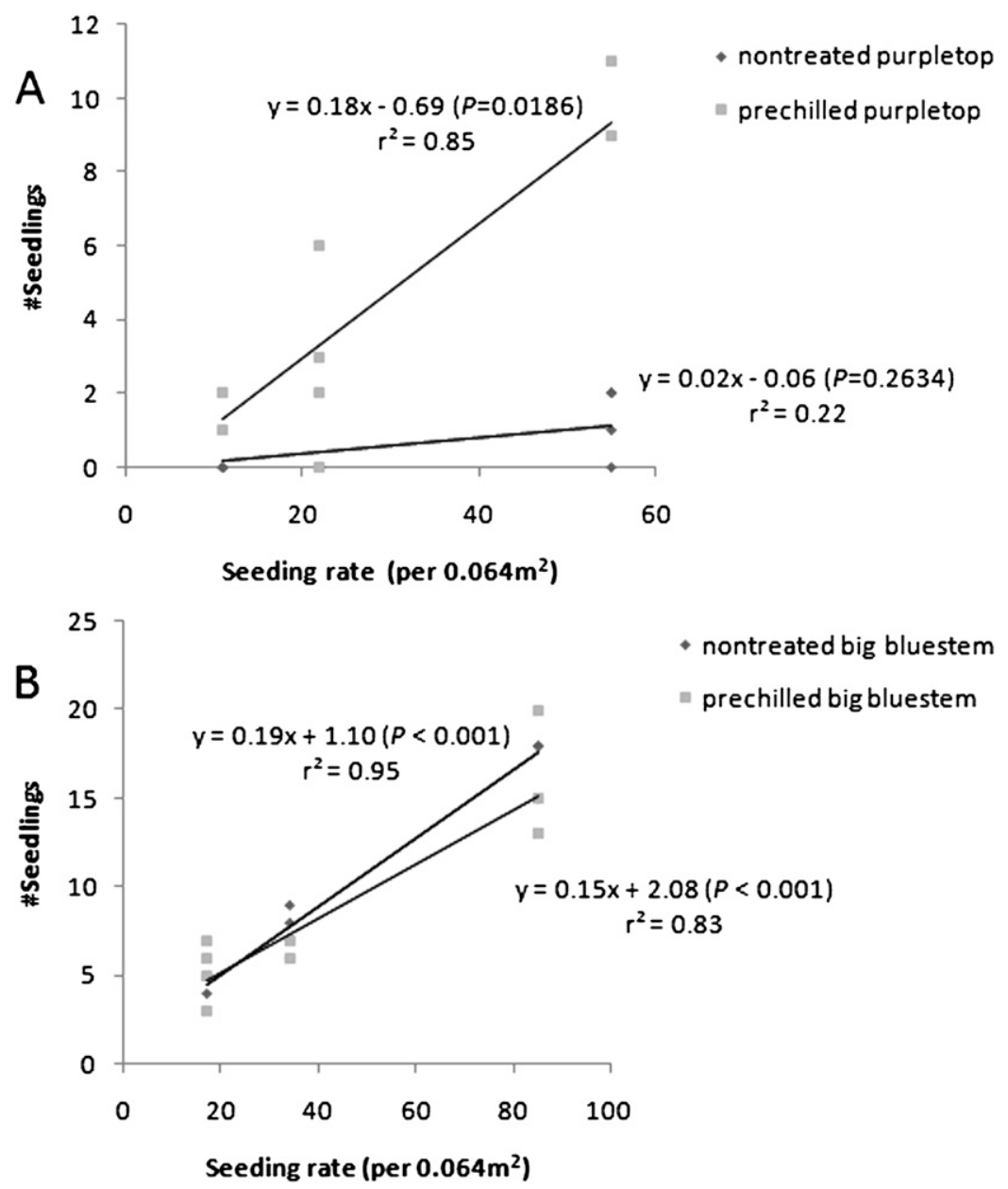

Fig. 2. Regressions of the number of seedlings emerged on seeding rate 4 weeks after planting warmseason grass seed mixes containing nontreated $(\bullet)$ or prechilled $(\boldsymbol{\square})$ caryopses. (A) Nontreated or prechilling $\left(14 \mathrm{~d}\right.$ at $5{ }^{\circ} \mathrm{C}$ in $\left.0.2 \% \mathrm{KNO}_{3}\right)$ effects on purpletop emergence and (B) nontreated or prechilling $\left(7 \mathrm{~d}\right.$ at $5{ }^{\circ} \mathrm{C}$ in $\left.\mathrm{dH}_{2} \mathrm{O}\right)$ effects on big bluestem emergence. Seeding rates are actual number of seeds per treatment plot $\left(0.064 \mathrm{~m}^{2}\right)$.

in increased root length; however, this effect on big bluestem was lost on storage (Table 2). Restriction of oxygen diffusion was suggested as a possible mechanism of warmseason grass seed dormancy (Coukos, 1944), and change in the gaseous environment has been associated with loss of dormancy in grass seed [review by Simpson (1990)]. It is possible that drying of prechilled big bluestem caryopses allowed for more oxygen diffusion into the seed than did nondried, prechilled (moist-sowed) caryopses placed directly on the slant testing apparatus, resulting in longer root lengths. For purpletop, however, dried-back prechilled caryopses subjected to 5 or $21^{\circ} \mathrm{C}$ storage reduced FGP and seedling shoot length, whereas nonstored, moist-sowed prechilled caryopses were most beneficial for purpletop germination and seedling growth.

Short-duration treatments of $\mathrm{NaOCl}$ were effective at controlling fungal proliferation during priming of corn caryopses (Parera and Cantliffe, 1991). Although it was hypothesized that $\mathrm{NaOCl}$ treatments would be beneficial to caryopses by disinfesting surfaces, the main effects of pre- and posttreatments of purpletop with $\mathrm{NaOCl}$ was decreased FGP seedling establishment, whereas, regardless of application rate, few nontreated purpletop caryopses emerged 4 weeks after sowing.

The results of this study show that germination of purpletop and big bluestem was improved by prechilling but that these changes may or may not be related to seedling establishment dependent on grass species. Increased seedling root length occurred if nonstored, prechilled caryopses were used rather than stored, prechilled caryopses; thus, prechilling treatments must be applied immediately before sowing. Seedling emergence of purpletop was enhanced by prechilling and our results indicate an improvement of purpletop establishment after incorporation of prechilled caryopses into a warm-season grass seed mix.

\section{Literature Cited}

AOSA. 2007. Rules for testing seeds. Assn. of Offic. Seed Analysts, Inc., Stillwater, OK.

Beckman, J.J., L.E. Moser, K. Kubik, and S.S. Waller. 1993. Big bluestem and switchgrass establishment as influenced by seed priming. Agron. J. 85:199-202.

Brown, L. 1979. Grasses, an identification guide. Houghton Mifflin Company, New York, NY.

Coukos, C.J. 1944. Seed dormancy and germination in some native grasses. J. Amer. Soc. Agron. 36:337-345.

Emal, J.G. and E.C. Conrad. 1973. Seed dormancy and germination in Indiangrass as affected by light, chilling, and certain chemical treatments. Agron. J. 65:383-385.

Foote, L.E. and J.A. Jackobs. 1966. Occurrence and stand density of Tridens flavus (L.) Hitchc. as related to some soil factors. Agron. J. 58:412-414.

Giuliano, W.M. and S.E. Daves. 2002. Avian response to warm-season grass use in pasture and hayfield management. Biological Conservation 106:1-9.

Gomez, K.A. and A.A. Gomez. 1984. Statistical procedures for agricultural research. 2nd ed. Wiley, New York, NY

Hardegree, S.P. 1994. Drying and storage effects on germination of primed grass seeds. J. Range Mgt. 47:196-199.

Hsiao, A.I. and W.A. Quick. 1985. Wild oats (Avena fatua L.) seed dormancy as influenced by sodium hypochlorite, moist storage and gibberellin $\mathrm{A}_{3}$. Weed Res. 25:281-288.

Hsu, F.H., C.J. Nelson, and A.G. Matches. 1985 Temperature effects on germination of perennial warm-season grasses. Crop Sci. 25:215-220.

Launchbaugh, J.L. and C.E. Owensby. 1970. Seeding rate and first-year stand establishment for six native grasses. J. of Range Mgt. 23:414-417.

Miller, C.F. and J.A. Dickerson. 1999. The use of native warm season grasses for critical area stabilization, p. 222-228. Proc. 2nd Eastern Grass Symp., Baltimore, MD.

Olszewski, M.W., W.G. Pill, D.A. Scheiblin, and K.J. Czymmek. 2009. Use of confocal microscopy to relate germination vigour to embryo morphology of dormant and non-dormant purpletop (Tridens flavus). Seed Sci. Technol. 37:52-58.

Parera, C.A. and D.J. Cantliffe. 1991. Improved germination and modified imbibitions of shrunken-2 sweet corn by seed disinfection and solid matrix priming. J. Amer. Soc. Hort. Sci. 116:942-945.

Phillips, C.E. 1962. Some grasses of the northeast. Univ. of DE Agricultural Expt. Sta., Newark, DE.

Robocker, W.C., J.T. Curtis, and H.L. Ahlgren. 1953. Some factors affecting emergence and 
establishment of native grass seedlings in Wisconsin. Ecol. 34:194-199.

Ross, M.A. and J.L. Harper. 1972. Occupation of biological space during seedling establishment. J. Ecol. 60:77-88.

Simpson, G.M. 1990. Seed dormancy in grasses. Cambridge University Press, Cambridge, UK.

Smith, O.E., N.C. Welch, and T.M. Little. 1973. Studies on lettuce seed quality: I. Effect of seed size and weight on vigor. J. Amer. Soc. Hort. Sci. 98:529-533.

USDA-NRCS. 1996. Establishment of native plants on disturbed sites. Jamie L. Whitten Plant Materials Center, Coffeeville, MS. Tech. Note 12(1). 5 Nov. 2008. <http://www.plant-materials.nrcs. usda.gov/pubs/mspmetn9601.pdf>.

USDA-NRCS. 2006. 2005 annual report. Jamie L. Whitten Plant Materials Center, Coffeeville,
MS. 5 Nov. 2008.<http://www.plant-materials. nrcs.usda.gov/pubs/mspmetr6778.pdf>.

USDA-NRCS. 2009a. Plants profile: Andropogon gerardii Vitman. Big bluestem. 11 Jan 2009. <http:// plants.usda.gov/java/nameSearch?keywordquery= big+bluestem\&mode $=$ comname $>$.

USDA-NRCS. 2009b. Plants profile: Tridens flavus (L.) Hitchc. Purpletop tridens. 11 Jan. 2009. <http:/ plants.usda.gov/java/profile?symbol=TRFL2 $>$. 